\title{
Comparison of PCR fingerprinting, by random amplification of polymorphic DNA, with other molecular typing methods for Candida albicans
}

\author{
Anne Bostock, M. N. Khattak, Ruth Matthews* and James Burnie \\ Department of Medical Microbiology, Stopford Building, Manchester University, Oxford Road, \\ Manchester M13 9PT, UK
}

(Received 25 November 1992; revised 19 February 1993; accepted 18 March 1993)

\begin{abstract}
Fingerprinting by random amplification of polymorphic DNA (RAPD) was compared with existing molecular typing systems for Candida albicans. Fifteen isolates were chosen, including three from the same patient; these gave 14 distinct karyotypes by pulsed-field gel electrophoresis (PFGE) and 7 different DNA types by EcoRIgenerated restriction fragment length polymorphisms (RFLPs). RAPD with primer I ( $5^{\prime}$ GCT GGT GG $3^{\prime}$ ) gave 5 types, whereas primer $\mathrm{I}\left(5^{\prime}\right.$ GCGCACGG3') yielded 11 types. Combining the results from both primers, all isolates were unique by RAPD with the exception of the three from the same patient. RAPD provided a fast, economical and reproducible means of typing $C$. albicans with a level of discrimination approaching that of PFGE.
\end{abstract}

\section{Introduction}

The polymerase chain reaction (PCR) can be adapted for fingerprinting micro-organisms by using paired primers derived from previously characterized sequences for PCR amplification. This has been applied to the human fungal pathogen Cryptococcus (Vilgalys \& Hester, 1990). Recently, a new DNA polymorphism assay has been developed based on PCR amplification of random DNA fragments with single short primers of arbitrary nucleotide sequence (Welsh \& McClelland, 1990; Williams et al., 1990). This method has the advantage that no prior sequence information is required. These polymorphisms have been termed random amplified polymorphic DNA (RAPD) markers (Williams et al., 1990). RAPD has been applied to two fungal plant pathogens, Fusarium solari (Crowhurst et al., 1991) and Leptosphaeria maculans (Goodwin \& Annis, 1991).

This paper describes the application of RAPD to the human fungal pathogen Candida albicans. C. albicans is a common cause of oral and vaginal infections and is

*Author for correspondence. Tel. (061) 275 5502; fax (061) 275 5504

Abbreviations: PFGE, pulsed-field gel electrophoresis; RAPD, random amplification of polymorphic DNA; RFLP, restriction fragment length polymorphism. increasingly the cause of severe systemic infections in immunocompromised patients (Odds, 1988; Edwards, 1991). To facilitate studies on the epidemiology of Candida, numerous phenotypic and genotypic typing systems have been developed. These have been reviewed by Merz (1990) who emphasized the potential of DNA typing systems such as restriction fragment length polymorphisms (RFLPs) and electrophoretic karyotypes. Digestion with a single restriction enzyme like $E c o$ RI yields several fragments present in high enough concentrations to give distinct bands on a stained electrophoretic gel (Scherer \& Stevens, 1987). These bands are derived from mitochondrial and ribosomal DNA and they vary sufficiently in size to permit the development of an epidemiologically useful typing system. This has been applied to the identification of outbreaks of candidosis (Matthews \& Burnie, 1989; Lee et al., 1991). Although RFLPs have the advantage of being easy and rapid to perform, they have the disadvantage that the number of possible types is limited, with certain patterns appearing very commonly so that sometimes geographically distinct strains appear identical (Lee et al., 1991; Magee et al., 1992). Greater resolving power can be achieved by using a moderately repeated DNA sequence as a probe (Olivo et al., 1987; Scherer \& Stevens, 1988; Soll et al., 1988) or by electrophoretic karyotyping by pulsed-field gel electrophoresis (PFGE) (Magee \& Magee, 1987; Snell et al., 
1987; Merz, 1990; Vazquez et al., 1991; Magee et al., 1992). The disadvantages of both of these procedures are the greater cost and time required compared to RFLP. We therefore investigated the use of RAPD to see whether this technique, which is very convenient, quick and economical to perform, could match the resolving power of electrophoretic karyotyping. It was applied to 14 isolates which appeared distinct by PFGE, and compared to EcoRI-generated RFLPs.

\section{Methods}

Strains. Fifteen isolates of C. albicans were examined, including 13 from 11 patients with disseminated candidosis. The isolates were identified as C. albicans by their assimilation pattern with the API $20 \mathrm{C}$ system (Bueschug et al., 1979) and by chlamydospore formation. Isolates 4,6 and 7 were from the same patient. Isolate 1 was the reference strain NCTC 3153 (serotype A) and isolate 48 was the reference strain NCTC 3156 (serotype B).

Preparation of yeast DNA for RFLP and RAPD. After overnight growth in $2 \%(\mathrm{w} / \mathrm{v})$ glucose nutrient broth, the yeast was harvested by centrifugation, washed in $1 \mathrm{M}$-sorbitol and incubated at $37^{\circ} \mathrm{C}$ for $40 \mathrm{~min}$ in $1 \mathrm{ml} \mathrm{SE}$ buffer ( $1.2 \mathrm{M}$-sorbitol, $0.1 \mathrm{M}$-EDTA pH 7.5) containing $1 \mu \mathrm{l} 2$-mercaptoethanol and $0.3 \mathrm{mg}$ yeast lytic enzyme (Zymolyase $100 \mathrm{~T}$, ICN Biochemicals). The resulting spheroplasts were harvested by centrifugation (2500 r.p.m. for $5 \mathrm{~min}$ ), washed in SE buffer and resuspended in $0.5 \mathrm{ml} 0.15 \mathrm{M}-\mathrm{NaCl} 0.1 \mathrm{M}$-EDTA $\mathrm{pH} 7.5$. They were lysed by the addition of proteinase $\mathrm{K}$ (final concentration $400 \mu \mathrm{g} \mathrm{ml}^{-1}$ ) and $\operatorname{SDS}(1 \%(\mathrm{w} / \mathrm{v})$ final concentration). RNAase was added $(20 \mu \mathrm{l}$ of a $20 \mathrm{mg} \mathrm{ml}^{-1}$ stock solution) prior to incubation at $55^{\circ} \mathrm{C}$ for $30 \mathrm{~min}$. After centrifugation, the supernatants were extracted twice with phenol/chloroform and once with chloroform. Then the DNA was precipitated with 2-propanol before dissolving in $50 \mu \mathrm{TE}$ buffer (10 mM-Tris, 0.1 mM-EDTA pH 8.0).

Generation of RFLP. A portion ( $45 \mu \mathrm{l})$ of each sample of Candida DNA in TE was digested to completion with EcoRI. Digests were analysed on a $20 \times 20 \mathrm{~cm}, 300 \mathrm{ml}$ horizontal $1.2 \%(\mathrm{w} / \mathrm{v})$ agarose gel in $1 \times$ TBE buffer ( 89 mM-Tris, 89 mm-boric acid, 2.5 mM-EDTA, pH 8.3) containing ethidium bromide $\left(0.5 \mu \mathrm{g} \mathrm{ml}^{-1}\right)$ and run at $35 \mathrm{~V}$ for $24-30 \mathrm{~h}$ with $H$ indIII-EcoRI digested phage lambda as size markers. It was photographed under UV illumination.

$R A P D$. To the remaining $5 \mu$ l of Candida DNA was added an equal volume of TE buffer. Then $2.5 \mu$ laliquots were used for the PCR, in a final reaction volume of $100 \mu \mathrm{l} 10 \mathrm{mM}$-Tris $/ \mathrm{HCl} \mathrm{pH} 8.8,50 \mathrm{mM}-\mathrm{KCl}$, $1.5 \mathrm{mM}-\mathrm{MgCl}_{2}$ containing $1 \mu \mathrm{g}$ of primer and $200 \mu \mathrm{M}$ of each dNTP. Magnesium titration indicated an optimal concentration of $1.5 \mathrm{~mm}$ $\mathrm{MgCl}_{2}$. The reaction mix was overlaid with mineral oil and subjected to an initial denaturation at $95^{\circ} \mathrm{C}$ for $10 \mathrm{~min}$. Then $2.5 \mathrm{U}$ Taq Polymerase (Northumbria Biologicals) were added and PCR was done on a Techne Mark 2 thermal cycler as follows: 1 min at $96^{\circ} \mathrm{C}, 2 \mathrm{~min}$ at $30^{\circ} \mathrm{C}, 2 \mathrm{~min}$ at $72{ }^{\circ} \mathrm{C}$. After completion of 45 cycles, the reaction was held at $72^{\circ} \mathrm{C}$ for $7 \mathrm{~min}$. Control tubes with no template DNA were included in each run.

Amplified products were resolved by gel electrophoresis on a horizontal, $10 \times 10 \mathrm{~cm}, 100 \mathrm{ml} 1.3 \%$ agarose gel in TBE buffer, containing $0.5 \mu \mathrm{g}$ ethidium bromide $\mathrm{ml}^{-1}$. HindIII-EcoRI digested phage lambda and HaelII digested $\phi$ X 174 DNA were used as molecular mass markers. The PCR products were resolved by electrophoresis at $50 \mathrm{~V}$ for $3 \mathrm{~h}$.

Primer synthesis. Oligodeoxynucleotide primers were synthesized by standard phosphoramidite chemistry on an Applied Biosystems PCR
MATE DNA synthesizer. After removal of protecting groups in ammonium hydroxide at $55^{\circ} \mathrm{C}$ overnight, the samples were dried under vacuum, dissolved in TE and used without further purification. Primer sequences ( 5 to 3 ) were as follows: no. I, GCT GGTGG and no. II, GCGCACGG (Caetano-Anolles et al., 1991).

PFGE. Cell samples were prepared as described previously by Khattak et al. (1992). Briefly, cells were washed twice in 50 mM-EDTA, $\mathrm{pH} 7.5$ and resuspended in the same buffer to make spheroplasts by incubating at $37^{\circ} \mathrm{C}$ for $20 \mathrm{~min}$ with $200 \mu 12 \mathrm{mg}$ yeast lytic enzyme $\mathrm{ml}^{-1}$ per $0.3 \mathrm{ml}$ of cell suspension. The cell-enzyme suspension was mixed with $0.9 \mathrm{ml} 2 \%$ low-temperature-gelling agarose and allowed to solidify in moulds at $20^{\circ} \mathrm{C}$ for $5 \mathrm{~min}$. The agarose plugs were then transferred to buffer [0.5 M-EDTA pH $8.0,0.01 \mathrm{M}$-Tris $/ \mathrm{HCl} \mathrm{pH} 7 \cdot 5,7.5 \%$ (v/v) 2mercaptoethanol] and incubated overnight at $37^{\circ} \mathrm{C}$. The plugs were washed three times in $50 \mathrm{~mm}$-EDTA pH 8.0 and cell lysis was completed by adding $0.01 \mathrm{M}$-Tris $/ \mathrm{HCl} \mathrm{pH} 7.5,0.5 \mathrm{~m}$-EDTA $\mathrm{pH} 8.0,1 \%$ (w/v) laurylsarcosine, $1 \mathrm{mg}$ Proteinase $\mathrm{K} \mathrm{ml}^{-1}$. This was incubated for $2 \mathrm{~d}$ with gentle shaking. Plugs were washed three times with $50 \mathrm{~mm}$-EDTA $\mathrm{pH} 8.0$ and loaded onto $1 \%(\mathrm{w} / \mathrm{v})$ agarose gels in $0.5 \% \mathrm{TBE}$. Electrophoresis was done in a Bio-Rad CHEF-DRII system for $40 \mathrm{~h}$ at $12^{\circ} \mathrm{C}$, with an electric field of $4.2 \mathrm{~V} \mathrm{~cm}^{-1}$ for $24 \mathrm{~h}$ with a pulse time of $300 \mathrm{~s}$ and at $2.4 \mathrm{~V} \mathrm{~cm}^{-1}$ for $48 \mathrm{~h}$ with a pulse time of $1200 \mathrm{~s}$. Gels were stained with ethidium bromide $\left(0.5 \mu \mathrm{g} \mathrm{m}^{-1}\right.$ in distilled water) for $15 \mathrm{~min}$ and destained in distilled water for $3 \mathrm{~h}$. DNA bands were visualized under UV light and photographed.

\section{Results \\ $R A P D$}

Both primers successfully typed all isolates examined (Tables 1 and 2, Figs 1 and 2). Discrimination was greatest with primer II, generating 11 types out of 15 isolates, whereas primer I produced 6 types. With both primers the three isolates from the same patient (isolates

\section{Table 1. RAPD fingerprinting of C. albicans with primer no. $I$}

(+), Faint band; DB, double band.

\begin{tabular}{rrrrrr}
\hline & \multicolumn{5}{c}{ Bands present } \\
Isolate \\
\cline { 2 - 6 } no. & 1 & 2 & 3 & 4 & $\begin{array}{c}\text { RAPD } \\
\text { type }\end{array}$ \\
\hline 4 & DB & DB & $(+)$ & + & 1 \\
111 & DB & DB & $(+)$ & + & 1 \\
232 & DB & - & + & + & 2 \\
1 & DB & $(+)$ & + & + & 3 \\
11 & DB & + & $(+)$ & + & 3 \\
8 & DB & - & + & + & 2 \\
22 & DB & DB & $(+)$ & + & 1 \\
21 & DB & + & + & + & 3 \\
48 & DB & DB & $(+)$ & + & 1 \\
617 & DB & + & - & $+*$ & 4 \\
214 & DB & - & - & + & 5 \\
373 & DB & + & $(+)$ & + & 3 \\
77 & DB & DB & - & + & 6 \\
6 & DB & DB & $(+)$ & + & 1 \\
7 & DB & DB & $(+)$ & + & 1 \\
\hline
\end{tabular}

* Extra band between bands no. 3 and 4 . 
Table 2. RAPD fingerprinting of $C$. albicans with primer no. $I I$

$(+)$, Faint band; DB, double band.

\begin{tabular}{rccccccccc}
\hline \hline & \multicolumn{7}{c}{ Bsands present } \\
Isolate \\
\cline { 2 - 9 } no. & 1 & 2 & 3 & 4 & 5 & 6 & 7 & 8 & $\begin{array}{c}\text { RAPD } \\
\text { type }\end{array}$ \\
\hline 4 & - & + & + & + & - & DB & - & - & 1 \\
111 & + & $(+)$ & + & + & - & + & - & - & 2 \\
232 & + & $(+)$ & + & DB & + & DB & + & - & 3 \\
1 & - & + & + & DB & + & DB & + & - & 4 \\
11 & + & $(+)$ & + & + & + & + & + & - & 5 \\
8 & + & + & + & + & - & DB & $(+)$ & - & 6 \\
22 & + & + & + & + & + & + & + & - & 7 \\
21 & - & + & + & + & - & DB & - & - & 1 \\
48 & + & $(+)$ & + & + & $(+)$ & + & - & - & 8 \\
617 & $(+)$ & $(+)$ & + & $(+)$ & - & DB & - & + & 9 \\
214 & - & $(+)$ & + & $(+)$ & - & DB & - & - & 1 \\
373 & + & - & + & + & + & + & $(+)$ & + & 10 \\
77 & + & $(+)$ & + & $(+)$ & - & - & - & - & 11 \\
6 & - & + & + & + & - & DB & - & - & 1 \\
7 & - & + & + & + & - & DB & - & - & 1 \\
\hline \hline
\end{tabular}

4, 6 and 7) were indistinguishable from each other. Reproducibility was assessed by repeating the preparation of DNA from the same isolate and amplifying by PCR on two different occasions. Sometimes the bands produced were less intense, but their overall position and whether they were present or absent was highly consistent.

Multiple bands were produced with primer I, but greatest variation occurred among two bands (numbers 2 and 3 ) just below the constant double band (number 1) at 564 bp (Fig. 1). These two bands were present, absent or of double width (Table 1). Band 4 was consistently present in all isolates. In the case of isolate 617 an extra band appeared just above band 4 .

With primer II, fingerprints were identified by differences in 7 of the 8 relatively intense bands in the size range between the 831 bp and the $3530 \mathrm{bp}$ markers (Fig. 2 , Table 2). Band 3 was constant. Bands 1,2 and 4-8 were variable, being present, absent or, in the case of isolates 4 and 6 , of single or double width.

\section{PFGE}

The 14 different PFGE karyotypes (Figs 3 and 4) were compared with a well-characterized reference strain, $C$. albicans SGY126 (Khattak et al., 1992), for estimation of the sizes of each band (Table 3). Bands at $3000 \mathrm{kbp}$, and $1700 \mathrm{kbp}$ were generally conserved and therefore unhelpful for typing. Bands at $1400 \mathrm{kbp}$ were sometimes replaced by a slightly higher band (isolates $4,21,617$ and 214) or an extra band occurred just below $1400 \mathrm{kbp}$ (isolates 6 and 7). Similar anomalies occurred with bands at $2200 \mathrm{kbp}$. The band at $2600 \mathrm{kbp}$ was often absent (isolates 4, 111, 232, 22, 214, 373 and 77). The bands at $1200 \mathrm{kbp}, 1070 \mathrm{kbp}$ and $1020 \mathrm{kbp}$ were reproducibly unresolvable for some isolates (numbers 4, 6, 7, 21 and 373). Consistent extra bands occurred below $1020 \mathrm{kbp}$ for isolates $8,22,48,617$ or above $1200 \mathrm{kbp}$ for isolate 373. The bands at $1070 \mathrm{kbp}$ and $1020 \mathrm{kbp}$ did not resolve well and only in isolates 617 and 214 could they be clearly distinguished. Of the three isolates from the same patient (Fig. 4), two were indistinguishable by PFGE (isolates 6 and 7 ) but one was clearly different (isolate 4).

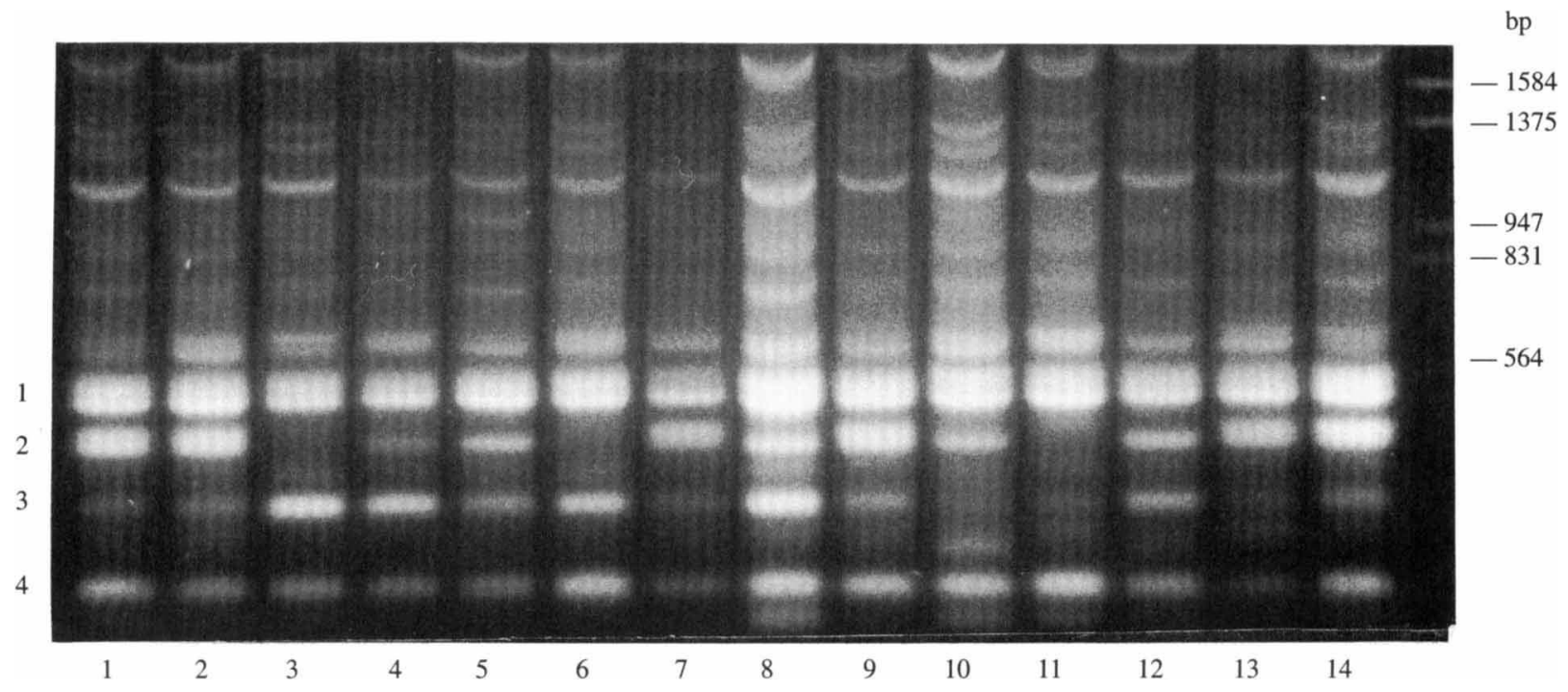

Fig. 1. RAPD fingerprinting with primer I (5'GCT GGT GG 3) showing isolates 4 (lane 1), 111 (2), 232 (3), 1 (4), 11 (5), 8 (6), 22 (7), $21(8), 48(9), 617(10), 214(11), 373(12), 77(13)$ and $6(14)$. Size markers are shown on the right-hand side and band numbers on the left. 


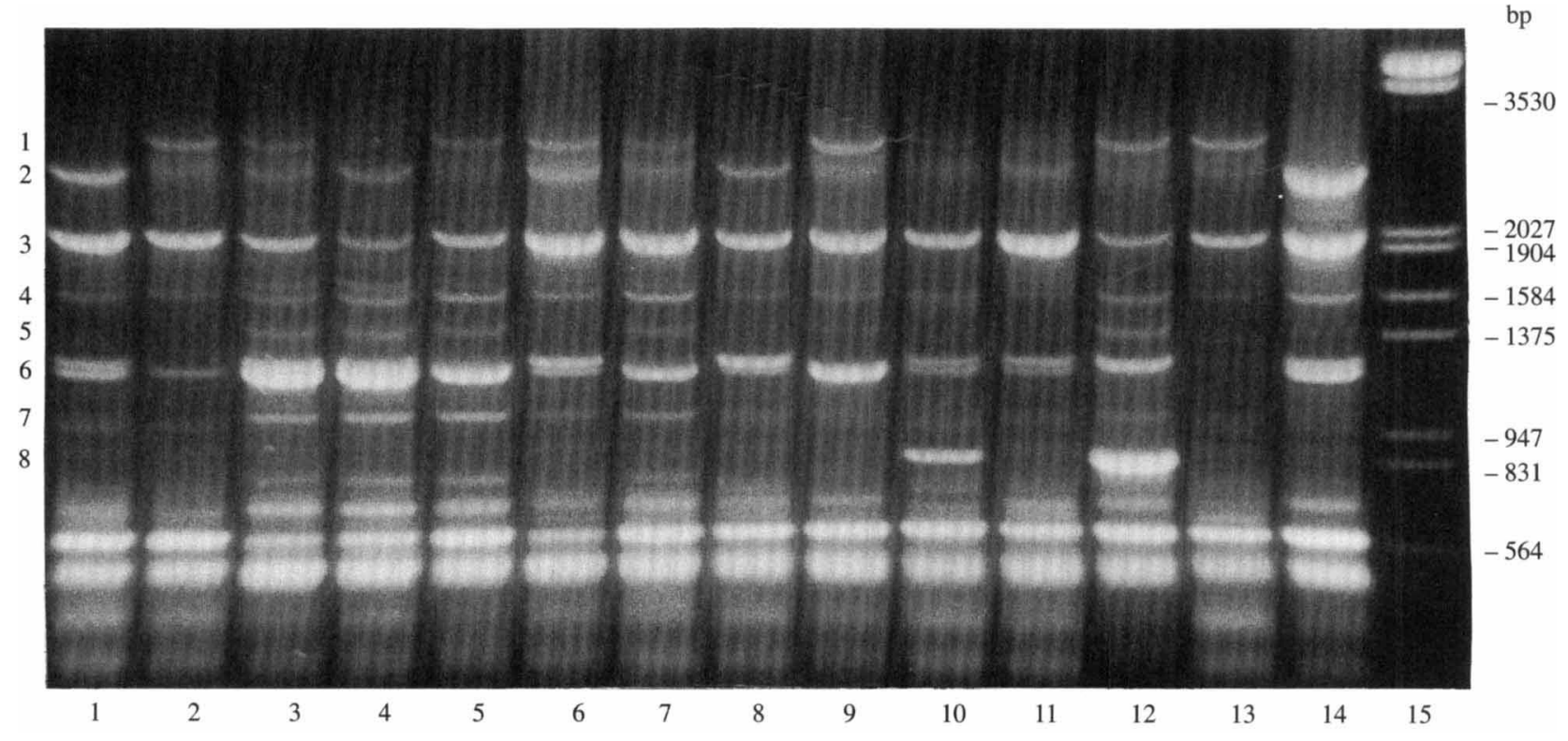

Fig. 2. RAPD fingerprinting with primer II (5'GCGCACGG3') showing isolates 4 (lane 1), 111 (2), 232 (3), 1 (4), 11 (5), 8 (6), 22 (7), 21 (8), 48 (9), $617(10), 214$ (11), 373 (12), 77 (13) and 6 (14). Lane 15, EcoR I-HindIII cut phage lambda with sizes given on the right. Band numbers are shown on the left.

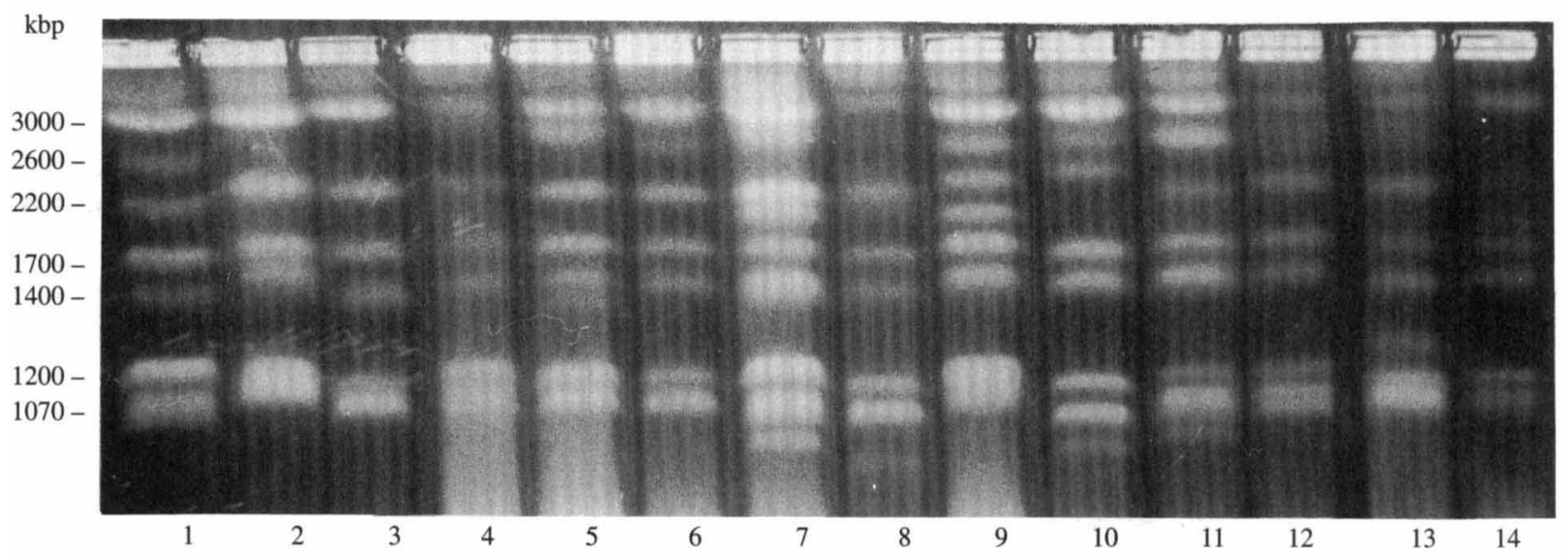

Fig. 3. PFGE karyotyping with isolates 4 (lane 2), 111 (3), 232 (4), 1 (5), 11 (6), 8 (7), 22 (8), 21 (9), 48 (10), 617 (11), 214 (12), 373 (13) and 77 (14). C. albicans reference strain SGY 126 is shown in lane 1 and sizes are given on the left.

\section{RFLP}

EcoRI-generated RFLP gave rise to 7 different types (Table 4), designated according to previously published criteria (Matthews \& Burnie, 1989; Lee et al., 1991).

\section{Discussion}

RAPD compared very favourably with other DNA typing systems for $C$. albicans. With 15 isolates representing 14 different PFGE karyotypes, RAPD with primer II generated 11 different types. Isolates 4, 6 and 7 were from the same patient, with systemic candidosis, number 4 being an antemortem blood culture isolate and numbers 6 and 7 being postmortem isolates collected $2 \mathrm{~d}$ later from the heart and meninges. The latter two isolates were indistinguishable from each other by PFGE but clearly different from the earlier isolate (Fig. 4). In contrast, all three isolates were indistinguishable by RAPD, even with the highly discriminatory primer II (Fig. 2, lanes 1 and 14). This raises the question as to whether, because of the propensity of $C$. albicans to genetic switching (Scherer \& Magee, 1990; Soll, 1992), typing by PFGE carries the risk of two genetically similar isolates appearing to be different because of a genetic rearrangement. Alternatively, two different 
Table 3. PFGE karyotypes of C. albicans isolates

$2200 \mathrm{~EB}$, extra band between 1700 and $2200 \mathrm{kbp} ; 1400 \mathrm{~EB}$, extra band just below $1400 \mathrm{kbp} ; 1200 \mathrm{~EB}$, extra band just above $1200 \mathrm{kbp} ; 1020 \mathrm{~EB}$, extra band running below $1020 \mathrm{kbp}$; $1020 \mathrm{DB}$, double band at $1020 \mathrm{kbp}$. UR, bands at 1200 and 1070 and $1020 \mathrm{kbp}$ unresolvable.

\begin{tabular}{|c|c|c|c|c|c|c|c|c|}
\hline \multirow[b]{2}{*}{$\begin{array}{c}\text { Isolate } \\
\text { no. }\end{array}$} & \multicolumn{7}{|c|}{ Size of bands present (kbp) } & \multirow[b]{2}{*}{$\begin{array}{c}\text { PFGE } \\
\text { type }\end{array}$} \\
\hline & 3000 & 2600 & 2200 & 1700 & 1400 & 1200 & $\begin{array}{c}1070 / \\
1020\end{array}$ & \\
\hline 4 & + & - & + & + & $+*$ & UR & LR & 1 \\
\hline 111 & + & - & + & + & + & $+\uparrow$ & + & 2 \\
\hline 232 & + & - & $+^{*}$ & + & + & + & + & 3 \\
\hline 1 & + & $+*$ & + & + & + & + & + & 4 \\
\hline $1 !$ & + & + & + & + & + & + & + & 5 \\
\hline 8 & + & + & EB & + & + & + & $\mathrm{EB}$ & 6 \\
\hline 22 & + & - & + & + & + & + & $\mathrm{EB}$ & 7 \\
\hline 21 & + & + & EB & + & $+*$ & LR & UR & 8 \\
\hline 48 & + & + & $+^{*}$ & + & + & + & EB & 9 \\
\hline 617 & + & + & + & + & $+^{*}$ & + & $\mathrm{DB} / \mathrm{EB}$ & 10 \\
\hline 214 & + & - & + & + & $+*$ & + & $\mathrm{DB}$ & 11 \\
\hline 373 & + & - & + & + & + & $\mathrm{EB} / \mathrm{UR}$ & UR & 12 \\
\hline 77 & + & - & + & + & + & + & + & 13 \\
\hline 6 & + & + & EB & + & EB & UR & UR & 14 \\
\hline 7 & + & + & $\mathrm{EB}$ & + & $\mathrm{EB}$ & UR & UR & 14 \\
\hline
\end{tabular}

* Band runs high. † Band runs low.

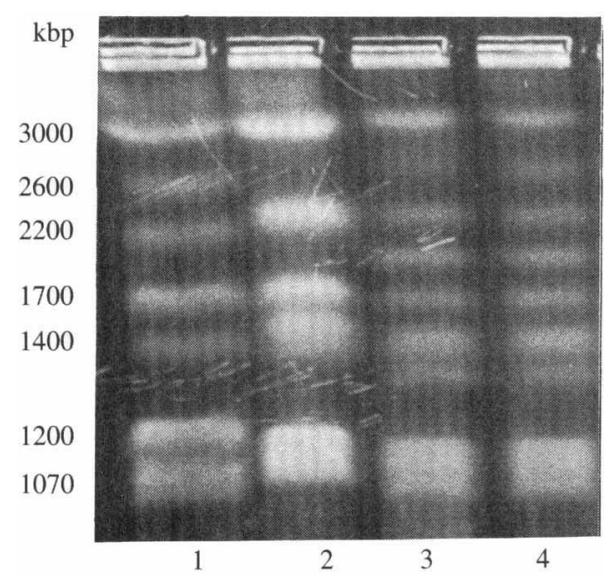

Fig. 4. PFGE karyotyping with three isolates from the same patient: isolates 4 (lane 2), 6 (3) and 7 (4). C. albicans SGY 126 (lane 1). Sizes are given on the left.

strains co-existed in this patient, which were differentiated by PFGE but not by RAPD or EcoRI-generated RFLP.

RAPD with primer I was less discriminatory than primer II, yielding only 5 types, but it was useful in increasing still further the discriminatory powers of primer II. Isolates 21 and 214 were indistinguishable from isolates 4,6 and 7 by RAPD with primer II, but clearly different with primer I. By combining the results obtained with both primers, we could identify each of the isolates as unique with the exception of the three isolates (numbers 4, 6 and 7) from the same patient. With the
Table 4. Comparison of molecular typing techniques

\begin{tabular}{|c|c|c|c|c|}
\hline \multirow{2}{*}{$\begin{array}{c}\text { Isolate } \\
\text { no. }\end{array}$} & \multirow{2}{*}{$\begin{array}{c}\text { PFGE } \\
\text { karyotype }\end{array}$} & \multicolumn{2}{|c|}{ RAPD } & \multirow{2}{*}{$\begin{array}{l}\text { RFLP } \\
\text { type }\end{array}$} \\
\hline & & Primer I & Primer II & \\
\hline 4 & 1 & 1 & ] & 14 \\
\hline 111 & 2 & 1 & 2 & 1 \\
\hline 232 & 3 & 2 & 3 & 2 \\
\hline 1 & 4 & 3 & 4 & 1 \\
\hline 11 & 5 & 3 & 5 & 2 \\
\hline 8 & 6 & 2 & 6 & 2 \\
\hline 22 & 7 & 1 & 7 & 6 \\
\hline 21 & 8 & 3 & 1 & 14 \\
\hline 48 & 9 & 1 & 8 & 4 \\
\hline 617 & 10 & 4 & 9 & 10 \\
\hline 214 & 11 & 5 & 1 & 2 \\
\hline 373 & 12 & 3 & 10 & 9 \\
\hline 77 & 13 & 1 & 11 & 2 \\
\hline 6 & 14 & 1 & I & 14 \\
\hline 7 & 14 & 1 & 1 & 14 \\
\hline $\begin{array}{l}\text { No. of } \\
\text { types... }\end{array}$ & 14 & 5 & 11 & 7 \\
\hline
\end{tabular}

same isolates, EcoRI-generated RFLP generated only 7 types. Although discrimination might be improved with multiple restriction enzymes, experience has shown that the number of possible types generated is limited and some patterns occur very commonly so that geographically distinct strains can appear identical (Vazquez et al., 1991; Magee et al., 1992). Greater discrimination can be achieved by Southern blotting against a suitable probe such as ribosomal DNA but this is relatively timeconsuming (Magee et al., 1987).

RAPD has the advantage of being the least labourintensive of these typing methods, requiring only small amounts of DNA and being relatively easy to standardize between laboratories. It requires little knowledge of the molecular biology of the species being examined and no sequence information is necessary. Unlike PCR typing performed with pairs of primers from a known sequence, it is not confined to changes occurring in only a small part of the genome. Each primer gives a different pattern of PCR products, and a primer with great potential for detecting polymorphisms within one species may be poorer at discriminating between the strains of another species. Sources of polymorphisms include deletions of a priming site and insertions that either increase the size of the PCR product or render the priming sites too distant to support amplification.

If a single DNA typing system is to be adopted, RAPD is probably the first choice for large-scale epidemiological studies of C. albicans. It is a quick, economical technique, with high reproducibility and typability, and provides a degree of discrimination approaching that of PFGE. The value of such epidemiological studies lies in the recent evolution of $C$. albicans as a major fungal pathogen in 
hospitals, including nosocomial outbreaks, as well as in the community and among patients with AIDS (Edwards, 1991).

\section{References}

Bueschug, W. J., KuReK, K. \& RonerTs, G. D. (1979). Evaluation of the modified API $20 \mathrm{C}$ system for identification of clinically important yeasts. Journal of Clinical Microbiology 9, 565-569.

Caetano-Anolles, G., Bassam, B. J. \& Gresshoff, P. M. (1991). DNA amplification fingerprinting using very short arbitrary oligonucleotide primers. Biotechnology 9, 553-556.

Crowhurst, R. N., Hawthorne, B. T., Rikkerink, E. H. A. \& Templeton, M. D. (1991). Differentiation of Fusarium solani f.sp cucurbitae races 1 and 2 by random application of polymorphic DNA. Current Genetics 20, 391-396.

EDwards, J. E. (1991). Invasive Candida infections. Evolution of a fungal pathogen. New England Journal of Medicine 324, 1060-1062

GoodwIN, P. H. \& ANNIS, S. L. (1991). Rapid identification of genetic variation and pathotype of Leptosphaeria maculans by random amplified polymorphic DNA assay. Applied and Environmental Microbiology 57, 2482-2486.

Khattak, M. N., Burnie, J. P., Matthews, R. C. \& Oppenheim, B. (1992). Clamped homogeneous electric field gel electrophoresis typing of Torulopsis glabrata isolates causing nosocomial infections. Journal of Clinical Microbiology 30, 2211-2215.

LeE, W., Burnie, J. P., MatThews, R. C., Oppenhetm, B. O. \& Damant, N. N. (1991). Hospital outbreaks with yeasts. Journal of Hospital Infection 18, 237-249.

MaGeE, B. B. \& MaGeE, P. T. (1987). Electrophoretic karyotypes and chromosome numbers in Candida species. Journal of General Microbiology 133, 425-430.

Magee, B. B., D'SouzA, T. M. \& Magee, P. T. (1987). Strain and species identification by restriction fragment length polymorphisms in the ribosomal DNA repeat of Candida species. Journal of Bacteriology 169, 1639-1643.

Magee, P. T., Bowdin, L. \& Staudinger, J. (1992). Comparison of molecular typing methods for Candida albicans. Journal of Clinical Microbiology 30, 2674-2679.
Matthews, R. C. \& BuRNie, J.P. (1989). Assessment of DNA fingerprinting for rapid identification of outbreaks of systemic candidiasis. British Medical Journal 298, 354-357.

Merz, W. G. (1990). Candida albicans strain delineation. Clinical Microbiology Reviews 3, 321-334.

ODDs, F. C. (1988). Candida and Candidosis : a Review and Bibliography, 2nd edn. London: Bailliere Tindall.

Olrvo, P. D., McManus, E. J., Riggsby, W. S. \& Jones, J. M. (1987). Mitochondrial DNA polymorphism in Candida albicans. Journal of Infectious Diseases 156, 214-215.

Scherer, S. \& MaGeE, P. T. (1990). Genetics of Candida albicans. Microbiological Reviews 54, 226-241.

SChFrer, S. \& Stevens, D. A. (1987). Application of DNA typing methods to epidemiology and taxonomy of Candida species. Journal of Clinical Microbiology 25, 675-679.

SCHFRER, S. \& STEVENis, D. A. (1988). A Candida albicans dispersed, repeated gene family and its epidemiologic applications. Proceedings of the National Academy of Sciences of the United States of America $85,1452-1456$.

SNell, R. G., Hermans, I. F., Wilkins, R. J. \& CORNer, B. E. (1987). Chromosomal variations in Candida albicans. Nucleic Acids Research 15,3625 .

SOLL, D. R. (1992). High-frequency switching in Candida albicans. Clinical Microbiology: Reviews 5, 183-203.

Soll, D. R., Staebell, M., Langtimm, C., Pfaller, M., Hicks, J. \& Gopala Rao, T. V. (1988). Multiple Candida strains in the course of a single systemic infection. Journal of Clinical Microbiology 26, $1448-1459$.

Vazquez, J. A., Beckley, A., Sobel, J. D. \& Zervos, M. J. (1991). Comparison of restriction enzyme analysis and pulsed-field gradient gel electrophoresis as typing systems for Candida albicans. Journal of Clinical Microbiology 29, 962-967.

Vilgalys, R. \& Hester, M. (1990). Rapid genetic identification and mapping of enzymatically amplified ribosomal DNA from several Cryptococcus species. Journal of Bacteriology 172, 4238-4246.

Welsh, J. \& MCClelland, M. (1990). Fingerprinting genomes using PCR with arbitrary primers. Nucleic Acids Research 18, 7213-7218.

Williams, J. G. K., Kubelik, A. R., LivaK, K. J., Rafalski, J. A. \& TINGEY, S. V. (1990). DNA polymorphisms amplified by arbitrary primers are useful as genetic markers. Nucleic Acids Research 18, $6531-6535$ 